Article

\title{
Organizational Happiness Dimensions as a Contribution to Sustainable Development Goals: A Prospective Study in Higher Education Institutions in Chile, Colombia and Spain
}

\author{
José Luis Silva Munar ${ }^{1}\left(\mathbb{D}\right.$, Susana De Juana-Espinosa ${ }^{2, *(D)}$, Laura Martínez-Buelvas ${ }^{3}$, \\ Yanina Vecchiola Abarca ${ }^{1}$ (D) and Joan Orellana Tirado ${ }^{1}$ \\ 1 Commercial Engineering Department, Faculty of Engineering, Universidad de Atacama, \\ 1530000 Copiapó, Chile; jose.silva@uda.cl (J.L.S.M.); yanina.vecchiola@uda.cl (Y.V.A.); \\ joan.orellana@uda.cl (J.O.T.) \\ 2 Faculty of Economics and Business, Universidad de Alicante, E-03690 Alicante, Spain \\ 3 Industrial Engineering Department, Faculty of Engineering, Universidad Tecnológica de Bolívar, \\ 130010 Cartagena de Indias, Colombia; Imartinez@utb.edu.co \\ * Correspondence: Susana.Espinosa@ua.es
}

Received: 25 November 2020; Accepted: 10 December 2020; Published: 15 December 2020

\begin{abstract}
The aim of this study is to reveal the perception of current and future organizational happiness in the context of higher education institutions (HEIs) in a cross-national study, to reveal exploratory scenarios supporting the UN's sustainable development goals (SDGs). Six dimensions of organizational happiness were considered for this study: Meaning, reliable relationships, positive emotions, engagement, achievement and recognition, and personal and professional development. To do so, Delphi methodology was used. An online survey was addressed to academics and support staff from three HEIs in different countries (Chile, Colombia and Spain), whose answers were analyzed using the Approximation of Qualitative Profiles mathematical technique. The results of this analysis show that there is a favorable prospective for happy workplaces, in all the dimensions for all countries. The implications of this research will serve HEIs' human management practitioners to formulate effective policies for sustainable workplaces based on organizational happiness.
\end{abstract}

Keywords: happiness dimensions; organizational happiness; cross-national research; prospective research; Delphi methodology

\section{Introduction}

The United Nations (UN) 2030 Agenda for Sustainable Development is one of the most ambitious and influential global agreements in recent years. This agenda [1] presents a framework of 17 sustainable development goals (SDGs) and 169 targets, which are based on the eight Millennium Development Goals of 2000, for the fight against poverty [2] and on a "universal call to action to end poverty, protect the planet and improve the lives and prospects of everyone, everywhere" [3] by 2030.

In particular, SDG No. 3 aims to ensure good health and well-being, which translates into guaranteeing the promotion of a healthy lifestyle and well-being for people of all ages [4], with a multidisciplinary approach [5]. This SDG is currently of special interest given the threat to global health posed by the COVID-19 pandemic. From an organizational perspective, this objective refers to the study of the factors and processes that may make people happy or unhappy at work [6]. Moraes and Barreiro [7] claim that the level of an employee's well-being or happiness at work can be explained both by the contribution of individual factors such as values, personality and goals, and the impact of 
organizational characteristics such as culture, work and the context in which they are developed. It has been shown that happiness depends on satisfaction with the environment and leadership, professional development, the characteristics of work and the level of person-environment fit [8]. There is sufficient evidence that researchers in the field of business organization have worked to better understand the role of work in the overall well-being of an individual $[9,10]$.

Among the managerial actions that can contribute to employee well-being and, subsequently, to the achievement of the strategic objectives of the organization is the concept of organizational happiness. This is a concept that stems from Seligman's [11] positive psychology theory, which refers to the generation of working conditions that facilitate the development of workers' skills [12]. Gutiérrez [13] argues that organizations are increasingly committed to strategies of change and organizational happiness in their programs to improve existing processes and subprocesses. Thus, the improvement in employees' quality of work-life has tangible and intangible benefits in terms of satisfaction, motivation and organizational commitment [14].

Higher education institutions (HEIs), in their multiple roles as educators, researchers, organizations, and community servers, also play an active part in the road to sustainable development $[15,16]$. The ideas and perceptions of HEI teachers and support staff are critical, since they teach and prepare future professionals, thus affecting social sustainability, as posited by Pfeffer [17]. Since embarking on the path of sustainability requires a profound transformation in the way people think and act [18], research on well-being and organizational happiness practices in HEIs is essential for the actual deployment of SDG No. 3. It is a paradox, then, that despite a proliferation of literature on the science of organizational happiness, there is little evidence of HEIs implementing happiness management models, and thus, inadequate knowledge on the effect on the academic performance of HEIs that do apply such a model.

Although there is scant evidence of the application of any happiness model in an HEI with a prospective view, a way to support sustainability development in HEIs is to generate exploratory scenarios whose vision of the future allows us to make decisions in the present. To bridge the research gap, this article presents the findings of an exploratory, cross-national Delphi study, which attempts to discover the perceptions of organizational happiness by HEI academics and support staff. The main contribution of this research is to better understand the factors that could be critical to improving the organizational happiness of HEI employees from an international perspective, and how this may contribute to SDG No. 3. Hence, the next section of this article explores the literature on organizational happiness, followed by a detailed description of the research methodology. The results are presented in Section 4 and discussed in Section 5, including several recommendations to managers and researchers.

\section{State of the Art}

\subsection{Organizational Happiness: The Concept and Its Effect on Performance}

Currently, organizational happiness is considered a multi-faceted research discipline. There is consensus that its management positively affects organizational climate and improves the productive performance of human capital. Organizational happiness is directed at the organization's ability to create and facilitate conditions and work processes that are conducive to nurturing individual and group strengths [12].

Happiness at work can be associated with greater professional success, higher income, better job performance and a tendency to help others in their jobs. It also may lead to efficiency and the achievement of organizational goals, which is the ultimate benefit that an organization could receive [19-21]. According to extant literature, a person who is happy at work is usually more creative and productive [9] and may also be effective, innovative, receptive, optimistic and altruistic [22-24].

Positive employee-related outcomes such as happiness and productivity can be facilitated by providing certain types of conditions in organizations. According to Gavin and Mason [25], these conditions should include providing employees with meaningful work and the scope for excellence and empathy, and satisfying employees' need for safety, trust and dignity. In addition, 
it allows employees to work by providing them with autonomy and information and facilitates the development of their character virtues.

\subsection{Dimensions for the Study of Organizational Happiness}

The discipline of positive psychology deals with the positive aspects of life, analyzing the impact of events from birth to death, and can make important contributions to good health and well-being [26]. It has contributed to the identification, development and evaluation of interventions aimed at improving well-being, justified in the approach toward recovering from mental health problems, or dealing with chronic physical illness or disability [27]. These contributions convey valuable lessons on how to build a happy, healthy, productive, and meaningful life [28]. In this sense, the study of happiness and well-being is associated with the basic framework of SDG No. 3.

The World Health Organization defines mental health as a "state of well-being in which the individual realizes their own abilities, can cope with normal life stresses, can work productively and fruitfully, and is able to do a contribution to their community" [29]. For this reason, it is considered that participation in positive activities increases the frequency of positive emotion, which, in turn, is associated with better physiological functioning and greater participation in preventive health behaviors, ultimately leading to improved physical and psychological well-being [30,31]. It has been shown that positive emotions, such as comfort, happiness, joy, love, and gratitude, can help maintain and improve human mental health [32,33]. In addition, other studies have shown that well-being at work is associated not only with health outcomes, but also with psychosocial factors related to work and performance [34].

Fisher [35] proposes that happiness at work should be treated as a multidimensional approach. The PERMA model captures this perspective, initially based on five dimensions of Positive Emotions, Meaning, Reliable Relationships, Engagement and Achievement and Recognition [36]. The model was later complemented by Fernández [12] with the Professional and personal development dimension, which assumes that the organization is ethically concerned and responsible for generating strategies and practices that allow the growth and development of its employees. Wagner et al. [37] state that all dimensions are strongly related to other indicators of well-being and that each of the dimensions of PERMA is positively related to well-being.

The dimensions of organizational happiness as per the PERMA model are described below.

(a) Positive motions: Refers to the opportunity to experience more positive than negative emotions [38]. Positive emotions expand the repertoire of people's ideas and actions, which then, serve to create lasting personal, intellectual, physical, psychological and social resources [39].

(b) Meaning: The degree to which a person understands the meaning of their life and feels that it has purpose [38]. How to build a social or transcendent meaning of their own work and an inspiring shared meaning in teams and in the organization because they are existential drivers to motivate people at work [12].

(c) Reliable relationships: The cultivation and care of significant relationships with others [38]. Edwards and Cable [40] claim that trust in interpersonal relationships has a positive and significant influence on job satisfaction.

(d) Engagement: Refers to a set of interests and foci with which people are engaged in ideas, purposes and causes that are significant for them [38]. Kahn [41] has defined this concept as employees who physically, cognitively, emotionally and mentally give their best to fulfill their roles. Engaged workers are more motivated and involved in their jobs and organizations, more productive and willing to go beyond what is expected of them to help their organizations survive and prosper [42]. It could even increase the quality of work [43].

(e) Achievement and recognition: Represents the goals achieved to develop skills and feel competent, because completing tasks, achieving results and showing good indicators are observable acts of achievement at work $[12,38]$. 
(f) Professional and personal development: Refers to the fact that the organization is responsible for generating strategies and practices that foster the growth and development of its employees. People who are happy in their work, feel their organization is concerned for their professional and personal development [12].

\subsection{SDGs and Organizational Happiness in HEIs}

Educational institutions are fundamental in regulating the interactions between human societies and their environment, and as active participants in sustainable development [44] in several ways. First, there is the transference of sustainability values and attitudes through the academic and professional training of their students. Therefore, the ideas and perceptions of teachers and support staff are decisive, since they teach and prepare future professionals [45], especially as embarking on the path of sustainability requires a profound transformation in the way people think and act [18]. For this to work, it is required that teachers and support staff must include sustainability principles in their practices from all perspectives [46].

Following this line of thought, the second way relates to employee management policies. Research has shown that individuals are happier in organizations whose activity is developed within a knowledge-intensive context, according to the theory of self-determination. There is also evidence supporting a positive relationship between people who work in HEIs and their job satisfaction [21,47], and that the academic environment has changed considerably in the last 20 to 30 years, with a significant increase in academic and occupational stress [48]. This can be attributed to the perception of having less autonomy and flexibility, increase in workload, ambiguity of roles, increase in the number of students, limited time and funding, scarce resources, a highly competitive environment, perceived lack of positive practices, poor supervision and poor relationships between coworkers [49,50].

Lastly, HEIs are organizations that are constantly transforming in the face of pressing needs, seeking to improve their surrounding community's sustainability, development and quality of life. The capacity for survival and adaptability that HEIs have demonstrated through their history has reinforced their strength to face relevant changes [51,52]. HEIs around the world are facing similar, complex problems, emerging from serious challenges to their autonomy, academic freedom, research, student work and evaluation, because of their dedication to building a global society that responds to the ideals of greater solidarity, human and social development. Since this is a global trend with social, cultural, political and economic implications, its significance underlines the need to better understand the phenomenon by examining the factors and problems in global and local contexts [53].

\section{Materials and Methods}

The general objective of this research is to prospectively study the dimensions of organizational happiness in staff of HEIs, specifically in three universities of Chile, Colombia and Spain. The specific research goals are the following:

1. To reveal the perceptions of the three groups of experts (academics and support staff) regarding the dimensions of organizational happiness within their respective HEIs.

2. To determine possible improvements or concrete actions suggested by the experts for each sub-dimension, as a prospective tool for present decision-making processes.

3. To analyze how these perceptions contribute to SDG No. 3, within an organizational context.

Despite the obvious cultural and linguistic similarities between the three countries, there are a few singularities that make this comparison interesting. Specifically, Hofstede's indulgence dimension refers to the extent to which people try to control their desires and impulses [54]. Citizens of indulgent countries, i.e., Colombia and, to a lesser extent, Chile, are inclined to revel in leisure with a positive outlook to life. According to the dimension scores published by [55], citizens living in more restricted societies like Spain tend to be less optimistic while perceiving that indulgent behaviors should be controlled. Similarly, the masculinity dimension varies between the studied countries, with Colombia 
leaning towards to a more masculine society, in which people are more concerned with success and status than the more feminine culture and well-being-oriented Chilean society, or the neutral Spain, where balancing and inclusive behaviors are more appreciated. Therefore, the perception of organizational happiness might also differ between cases. Although there are some other aspects related to the cultural and gender dimensions, as well as other cultural dimensions, these are the most interesting features to consider for the specific purposes of this research.

This exploratory research was carried out using Delphi methodology complemented with the mathematical tool Approximation of Qualitative Profiles (AQP). This tool obtains a synthesis value through the distance function or defined measurement in a given data set to summarize the opinion of experts regarding the future state of an indicator [56]. Arape [56] states that prospective research is useful for visualizing future scenarios and monitoring corrective management. A prospective study, like this one, seeks to predict a certain behavior considering both internal and external factors that may enable, contextualize and/or constrain the future action [57]. Thus, the use of the Delphi technique $[56,58,59]$ aims to build scenarios based on the behavior of one or several variables. In fact, Murphy et al. [60] argue that the Delphi method has been frequently used to obtain information about the future and has been defined as a method of structuring a group communication process, which allows individuals, as a whole, to address a complex problem.

A questionnaire was prepared based on the six dimensions of organizational happiness according to the extended PERMA model [12], to be evaluated based on the Likert scale shown in Table 1 . Each dimension has been divided into the subdimensions derived from a literature review in the form of statements (see Table 2). The research has been developed considering scenarios ten years into the future, which is estimated as the time it would take for these dimensions to be incorporated into organizational decision-making in the field of people management.

Table 1. Likert scale with associated linguistic tags.

\begin{tabular}{cc}
\hline Number & Associated Linguistic Tag \\
\hline 1 & Significant decline \\
2 & Decline \\
3 & Mild decline \\
4 & No change \\
5 & Slight improvement \\
6 & Improvement \\
7 & Significant improvement \\
\hline
\end{tabular}

Since this was a cross-sectional study, the panel of surveyed experts consisted of several academic and administrative staff, under permanent or temporary contracts working for the three universities. The respondents were chosen through a non-probabilistic technique with a convenience sample, which included academic and administrative staff from a macro-unit of each of the three HEIs. In the Universidad de Atacama, and the Universidad Tecnológica de Bolívar, the study was conducted in the Faculty of Engineering, and in the Universidad de Alicante, it was developed in the Institute of Tourism Research. Most of the respondents were in teaching positions, which strengthened the research because teachers are the most important drivers of the process of educational restructuring and moving educational institutions toward sustainability [15].

All respondents were informed that they would be required to participate in a second round of questions, and were assured that their identity would not be in any way disclosed to any third party. They were also notified that their individual responses would be registered anonymously and treated in an aggregated manner before they participated in the study. 
Table 2. Dimensions and subdimensions of organizational happiness.

\begin{tabular}{|c|c|c|}
\hline Dimension & Subdimension & Referenced Works \\
\hline Positive emotions & $\begin{array}{l}\text { Positive attitude when problems in their area are discussed } \\
\text { Positive motivation with desire to work hard } \\
\text { Positive thoughts and feelings at work } \\
\text { Ability to disconnect when going home } \\
\text { Ability to manage stress (emotional effort) }\end{array}$ & {$[38,39,61-63]$} \\
\hline Meaning & $\begin{array}{l}\text { Interest in complementing work with that of others for a higher purpose } \\
\text { Feeling that the work is full of meaning and purpose } \\
\text { Interest in learning something new and interesting } \\
\text { Feeling that their work contributes to creating a better society } \\
\text { Feeling that their work is important in achieving the area's goal }\end{array}$ & {$[12,38,61-64]$} \\
\hline Reliable relationships & $\begin{array}{l}\text { Ability to provide emotional and professional support when someone in their work needs it } \\
\text { Valuing the work of others } \\
\text { Satisfaction of feeling part of the work team in the area } \\
\text { Satisfaction of feeling accepted by coworkers } \\
\text { Interest in the well-being of those who make up the area } \\
\text { Interest in participating in social networks in the area } \\
\text { Trust between people in the area } \\
\text { Fair and respectful treatment among colleagues } \\
\text { Ability to resolve conflicts in an effort to achieve common goals }\end{array}$ & {$[38,40,61,62,64]$} \\
\hline Engagement & $\begin{array}{c}\text { Pride in belonging to the area where he or she works } \\
\text { Considers work as inspirational } \\
\text { Pride in the work he or she does } \\
\text { Feel like going to work in the morning }\end{array}$ & {$[38,41-43,65]$} \\
\hline Achievement and recognition & $\begin{array}{l}\text { Support from the management } \\
\text { Recognition of their effort and achievements } \\
\text { Enough time to achieve the goals that have been set at work } \\
\text { Satisfaction with personal achievements obtained from work } \\
\text { Possibility of promotion in accordance with effort }\end{array}$ & {$[12,38,61]$} \\
\hline Professional and personal development & $\begin{array}{c}\text { Satisfaction because their work aligns with their interests, skills, and personality } \\
\text { Satisfaction because their work provides opportunities for growth and development } \\
\text { Possibility of receiving training to help them develop their careers } \\
\text { Time that allows for recreational, sports or leisure activities } \\
\text { Possibility of receiving feedback on their work } \\
\text { Possibility of expressing what they think and the need for their development } \\
\text { Possibility of having autonomy or freedom to guide the company's development }\end{array}$ & {$[12,61,66]$} \\
\hline
\end{tabular}


The questionnaire was sent out electronically on two occasions: in October and November 2019. Each round corresponds to a step in the Delphi methodology. The first round gathered the individual qualitative assessments of the respondents in regard to the organizational happiness dimensions, as well as a set of open questions for the respondents to propose sustainable measures for organizational happiness. The second round offered the participants feedback on the summarized values per dimension, qualitative and quantitative, so that they could review and discuss their assessments and prospects considering the overall perceptions.

The number of responses per case study and rounds of questions are shown in Table 3. In total, 43 responses were obtained in the first round and 36 in the second round. These numbers are considered sufficient, since the recommended number is between ten and thirty for the current method $[67,68]$. In all cases, the expected sample size was met for the purpose of controlled feedback [56]. Lost responses between rounds are a common and expected phenomenon in Delphi methodology [69]. The dates set for each round (October and November 2019), were defined according to the research project planning and the academic activity in the three universities, with prior coordination among the researchers.

Table 3. Reponses by country and round.

\begin{tabular}{lccc}
\hline & Chile & Colombia & Spain \\
\hline 1st round & 19 & 12 & 12 \\
2nd round & $12(63.2 \%)$ & $12(100 \%)$ & $12(100 \%)$ \\
\hline
\end{tabular}

To deal with the marked but reasonable variability of the opinions of the participants, the AQP technique was applied to compute the basic range profile that best synthesizes the opinion of all participants in the three universities [56]. Following this technique, the distance between the opinion profile of the group and the seven basic profiles of ranges from $i$, equaling one to seven, is calculated. This is represented as (1):

$$
d\left(\overline{O G}, \bar{C}_{i}\right)
$$

where:

$\overline{O G}=$ Scale that associates numbers with each opinion profile of the group.

$\overline{C_{i}}=$ The seven basic profiles of ranges, in this case $i=1$ to 7 .

In the second round of opinion, there were similar distance functions related to concepts of topology in mathematics because, in all three universities, there were twelve opinions of experts each, as represented in (2).

$$
|\cdot|_{i}=\left[\sum_{j=1}^{12}\left|\overline{O G_{j}}-\bar{C} i_{j}\right|^{i}\right]^{\frac{1}{i}}
$$

where:

${\overline{C_{i j}}}^{i}=j$ th component of $\overline{C_{i}}$

$\overline{O G}_{j}=j$ th component of the twelve of $\overline{O G}$

According to the proposed methodology, the NORMA-1- $\left(\|\cdot\|_{1}\right)$ distance was initially used. When two or more basic profiles of ranges with equal distance to the opinion profile of the group was the outcome, then the NORMA-2- $\left(\|\cdot\|_{2}\right)$ distance was used [56].

\section{Results}

\subsection{Control Variables}

Before analyzing the research results, a Chi-squared test was used to analyze if there were any differences in the perspectives of the consulted experts with respect to some control variables, such as gender, country and tenure, on the probability of finding happiness at work. 
In this instance, as seen in Table 4, 100\% of the women and $75 \%$ of the men believe that they can be happy in their workplace. Furthermore, $25 \%$ of Chilean male respondents do not believe workplace happiness is possible. In these three cases, the respondents have been at the institution for more than twelve years, and each one justifies their response differently: (a) there is little time to develop professionally, (b) organizational leadership is disastrous and (c) that the work environment is bad. An $\chi^{2}$ test result was $2.553(\mathrm{dof}=1)$ with a $p$-value of 0.110 ; therefore, it cannot be said that there are any significant differences between men and women in their belief regarding attaining happiness at work. In addition, $\chi^{2}=4.074(\mathrm{dof}=2)$ with a $p$-value of 0.13 means that there are no significant gender differences between countries either.

Table 4. Belief in happiness being found at work by gender.

\begin{tabular}{ccccccccc}
\hline Country & \multicolumn{2}{c}{ Men } & \multicolumn{2}{c}{ Percentage } & \multicolumn{2}{c}{ Women } & \multicolumn{2}{c}{ Percentage } \\
\hline Chile & Yes & No & Yes & No & Yes & No & Yes & No \\
& 9 & 3 & $75 \%$ & $25 \%$ & 7 & 0 & $100 \%$ & $0 \%$ \\
\hline Colombia & Yes & No & Yes & No & Yes & No & Yes & No \\
& 5 & 0 & $100 \%$ & $0 \%$ & 7 & 0 & $100 \%$ & $0 \%$ \\
\hline Spain & Yes & No & Yes & No & Yes & No & Yes & No \\
& 7 & 0 & $100 \%$ & $0 \%$ & 5 & 0 & $100 \%$ & $0 \%$ \\
\hline
\end{tabular}

\subsection{First Round}

Although this study has a prospective approach, it was considered relevant to include the results of the first round of the survey, in the capacity of a primary input for decision-making. As stated earlier, in the first round, the instrument was applied to 43 people who work in universities in Chile (19), Colombia (12) and Spain (12). In this round, participants had to allocate scores from one to seven to certain statements occurring in six dimensions of happiness. The current scenario is first scored, then the future one and finally, the respondents suggest corrective actions to reach a maximum score.

In relation to the current and future evaluation, it could be seen that in all dimensions of the model, Chile was below the global average, Colombia was above the average, and Spain was above or equal to the global average. Spain's evaluations, current and future, were all bordering on a score of six.

The next step in the research was to consider each happiness dimension separately. When asked about possible harmful factors, the respondents had focused on three ideas. The factor with the greatest impact is the work environment (dishonesty, individualism, distrust, etc.). Then, there is lack of direction (incompetent, bad practices, conflict of interest, among others) and impartiality and favoritism. In Chile, work climate and lack of direction stand out; in Colombia, work climate, impartiality, and favoritism; and in Spain, only the work climate is mentioned.

On the positive side, when asked for proposals of specific actions that would help reach the maximum score in each subdimension, only $50 \%$ of the total respondents provided possible improvement measures. Some of the proposed actions for achieving organizational happiness are summarized in Table 5. This table recaps the most representative ideas that were repeated by different respondents and answers the second research proposition.

With respect to the most relevant dimensions of organizational happiness for HEI professionals in the countries studied, it can be established that all of them present an optimistic outlook for the future: the future evaluation in $100 \%$ of the cases was higher than the current one. This is illustrated in Figure 1. The dimension Achievement and recognition obtained the greatest dispersion in its responses, with a standard deviation of 1.7 points. The worst-scored question arose under the Professional and personal development dimension, in which the respondents claimed they did not have enough time for recreational, sports or leisure activities. In the Meaning dimension, all respondents expressed considerable interest in learning something new and interesting. 


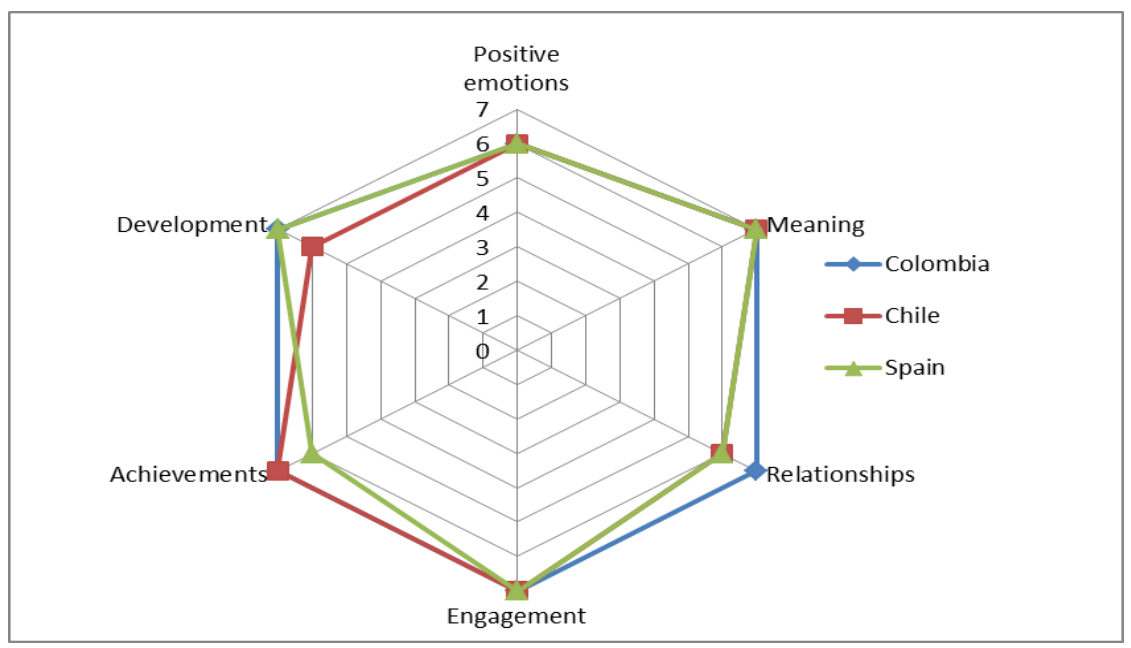

Figure 1. Synthesis values for Chile, Colombia and Spain, 1st round.

In general, the synthesis scores tend to be homogeneous for each dimension regardless of the ranking above or below average scores. Experts were asked for feedback only for the first-round scores, since the focus of the second set of questions is on prospective values, that is, the outlook of the dimensions under study.

\subsection{Second Round}

In the second round, the survey was answered by 36 people, 12 for each university involved. The dimensions and subdimensions of organizational happiness are the same as in the first round, as described in Table 2.

The synthesis values for each major dimension of organizational happiness were calculated with the AQP tool, yielding relevant scores related to the most representative scenarios of the respondent's desired future. These results have been presented by dimension and could be a primary input for decision-making regarding happiness at work in HEIs. The results for the three universities are illustrated in Table 6.

The results reflect the perceived reality about organizational happiness in academic environments, showing a strong tendency toward expressions six (improvement) and seven (significant improvement) for most of its dimensions. The Meaning dimension had the best average score among the respondents, since most expressed considerable interest in learning something new and interesting. The Positive Emotions dimension is one of the critical areas of happiness management to be prioritized; that is, work should be done to promote positive experiences and emotions among the staff, enabling them to innovate and take pleasure in their work.

According to the results of the exploratory scenario by country, for Chile, by the end of 2030, two-thirds of the indicators are expected to improve and one-third are expected to show significant improvement. In the case of the Colombian panel, it is expected that by the end of 2030, one-third of the indicators will show improvement, while the other two-thirds will show significant improvement. In the case of the Spanish institution, by the end of 2030,100\% of the indicators are expected to show improvement. A comparison of the results by dimensions and countries is illustrated in Figure 2. 
Table 5. Proposed actions for organizational happiness by country and dimension.

\begin{tabular}{|c|c|c|c|c|c|c|}
\hline Country & Positive Emotions & Meaning & Relationships & Engagement & Achievements & Development \\
\hline Chile & $\begin{array}{l}\text { Time for family life. } \\
\text { Change of paradigms } \\
\text { toward positivism. } \\
\text { Balance the workload in } \\
\text { teaching, research, } \\
\text { commitment, } \\
\text { and management. } \\
\text { Making fair decisions. } \\
\text { Improve communication. } \\
\text { Reinforce critical thinking. }\end{array}$ & $\begin{array}{l}\text { Constructive communication. } \\
\text { Generation of a community } \\
\text { with inclusive interest groups. } \\
\text { Generate practice of new } \\
\text { ideas and incorporate } \\
\text { sustainable development. } \\
\text { Practice the assessment of } \\
\text { academic contributions. } \\
\text { Lead with goals of } \\
\text { greater relevance. } \\
\text { Practice openness } \\
\text { in knowledge. }\end{array}$ & $\begin{array}{l}\text { Improve the work } \\
\text { environment. } \\
\text { Practice informal } \\
\text { conversation. } \\
\text { Work toward leadership. } \\
\text { Work on open-mindedness } \\
\text { toward differences and } \\
\text { diversity in thinking. } \\
\text { Companionship meetings. } \\
\text { Practice respect, tolerance, } \\
\text { and good language. } \\
\text { Practice fair treatment. } \\
\text { Equitable plans. } \\
\text { Coaching to leave the battle } \\
\text { between egos behind. }\end{array}$ & $\begin{array}{l}\text { Make the area visible } \\
\text { to the community. } \\
\text { Recognize progress. } \\
\text { Reflect on the } \\
\text { progress achieved. } \\
\text { Support from } \\
\text { management. } \\
\text { Respect autonomy. }\end{array}$ & $\begin{array}{l}\text { Validate authorities. } \\
\text { Recognize tasks. } \\
\text { Review excess } \\
\text { academic load } \\
\text { Review incentive } \\
\text { and recognition. } \\
\text { Review administrative } \\
\text { processes with equity. } \\
\text { Balance time for teaching, } \\
\text { research, engagement, } \\
\text { and management tasks. } \\
\text { Form work teams for more } \\
\text { ambitious goals. }\end{array}$ & $\begin{array}{l}\text { Improve assessment instruments } \\
\text { Communication and } \\
\text { work environment. } \\
\text { Possibility of having } \\
\text { specialized training. } \\
\text { An intimate cafeteria for } \\
\text { conversation is required. } \\
\text { Tolerance to differences and } \\
\text { diversity of thought. } \\
\text { Regularization of } \\
\text { academic careers. } \\
\text { Encourage academic promotion. } \\
\text { Fostering collaborative } \\
\text { environments. }\end{array}$ \\
\hline Colombia & $\begin{array}{l}\text { Efficient management } \\
\text { of resources. } \\
\text { Willingness to change. } \\
\text { Generation of spaces for } \\
\text { interaction outside } \\
\text { the classroom. } \\
\text { Prioritize activities aimed } \\
\text { at focusing on the self. } \\
\text { Greater participation of } \\
\text { program managers in } \\
\text { decision-making. } \\
\text { Improve planning of } \\
\text { the area. } \\
\text { Efficient and consistent } \\
\text { assignment of tasks } \\
\text { Balance the workload in } \\
\text { teaching, research, } \\
\text { extension, } \\
\text { and administration. }\end{array}$ & $\begin{array}{l}\text { Encourage teamwork. } \\
\text { Generation of healthy spaces } \\
\text { for discussion on the } \\
\text { importance of teaching in the } \\
\text { building of society. } \\
\text { Programs on stress } \\
\text { management } \\
\text { Publicize organizational } \\
\text { policies and strategies at } \\
\text { all levels. } \\
\text { Clarity in the objectives and } \\
\text { results expected from } \\
\text { the staff. } \\
\text { Motivation. } \\
\text { Knowledge of how the } \\
\text { faculty operates. } \\
\text { Recognition of achievements. }\end{array}$ & $\begin{array}{c}\text { Trust and empathy } \\
\text { between peers. } \\
\text { Recognition for the work. } \\
\text { Maintain common goals } \\
\text { and interests. } \\
\text { Promote spaces for recreation. } \\
\text { Detect potential causes } \\
\text { of conflict. } \\
\text { Training in topics related to } \\
\text { human relations } \\
\text { and proactivity. } \\
\text { Efficient feedback of } \\
\text { performance. } \\
\text { Improve communication } \\
\text { with students and graduates. }\end{array}$ & $\begin{array}{l}\text { Work in what you are } \\
\text { passionate about } \\
\text { Generate identity } \\
\text { with the departmental } \\
\text { and institutional goals. } \\
\text { Align personal and } \\
\text { institutional interests. } \\
\text { Improve economic } \\
\text { conditions. } \\
\text { Recognition of work. } \\
\text { Motivational talks. }\end{array}$ & $\begin{array}{c}\text { Socialization of } \\
\text { achievement. } \\
\text { Improve the planning and } \\
\text { organization of the work of } \\
\text { the faculty. } \\
\text { Encourage staff to take on } \\
\text { new challenges. } \\
\text { Promote based on } \\
\text { experience, commitment, } \\
\text { and performance. } \\
\text { Concentration in the areas } \\
\text { of expertise to achieve } \\
\text { better results. }\end{array}$ & $\begin{array}{l}\text { Work with passion. } \\
\text { Know more about the plans and } \\
\text { incentives to achieve the } \\
\text { faculty's goals. } \\
\text { Maintain communication } \\
\text { channels. } \\
\text { Empathy between peers. } \\
\text { Prioritize recreational or leisure } \\
\text { activities. } \\
\text { More flexible hours. } \\
\text { Generate spaces to express needs. }\end{array}$ \\
\hline
\end{tabular}


Table 5. Cont

\begin{tabular}{|c|c|c|c|c|c|c|}
\hline Country & Positive Emotions & Meaning & Relationships & Engagement & Achievements & Development \\
\hline Spain & $\begin{array}{l}\text { Stress management. } \\
\text { Mindfulness classes. } \\
\text { Work-life balance } \\
\text { Leisure time. } \\
\text { Collaboration between } \\
\text { colleagues. }\end{array}$ & $\begin{array}{l}\text { Impactful work. } \\
\text { Encourage teamwork. } \\
\text { Improve recognition at the } \\
\text { institutional level. } \\
\text { Free up work time } \\
\text { to innovate. } \\
\text { Greater social recognition of } \\
\text { the profession. }\end{array}$ & $\begin{array}{l}\text { Help the youngest. } \\
\text { Improve leadership. } \\
\text { Instill engagement } \\
\text { in everyone. } \\
\text { Separate professional and } \\
\text { personal relationships. }\end{array}$ & $\begin{array}{c}\text { Management of } \\
\text { conflict resolution. } \\
\text { Improving self-esteem in } \\
\text { those who need it. } \\
\text { Leadership and presence } \\
\text { of the bosses. } \\
\text { Improve and publicize } \\
\text { the causes of } \\
\text { professional promotion. } \\
\text { Bureaucracy prevents the } \\
\text { use of time for more } \\
\text { creative tasks. } \\
\text { Recognition of } \\
\text { classmates. }\end{array}$ & $\begin{array}{l}\text { Always achieve the } \\
\text { support of the boss. } \\
\text { Achieve external } \\
\text { recognition. } \\
\text { Balancing workload. } \\
\text { Promote according to the } \\
\text { level of effort. } \\
\text { Eliminate favoritism and } \\
\text { recognize the true work } \\
\text { of years. }\end{array}$ & $\begin{array}{l}\text { More human and less } \\
\text { technical training. } \\
\text { Spaces to express what one } \\
\text { thinks and feels. } \\
\text { Live longer and work less } \\
\text { Improve communication } \\
\text { channels. }\end{array}$ \\
\hline
\end{tabular}

Table 6. Results of the second round: prospective values of happiness dimensions in Chile, Colombia, and Spain.

\begin{tabular}{|c|c|c|c|c|c|c|}
\hline Chile & Positive Emotions & Meaning & Relationships & Engagement & Achievements & Development \\
\hline Synthesis value & (6) & (7) & (6) & (6) & (7) & (6) \\
\hline Tag & Improvement & Significant improvement & Improvement & Improvement & Significant improvement & Improvement \\
\hline Colombia & Positive emotions & Meaning & Relationships & Engagement & Achievements & Development \\
\hline Synthesis value & (6) & (7) & (7) & (7) & (6) & (7) \\
\hline Tag & Improvement & Significant improvement & Significant improvement & Significant improvement & Improvement & Significant improvement \\
\hline Spain & Positive emotions & Meaning & Relationships & Engagement & Achievements & Development \\
\hline Synthesis value & (6) & (6) & (6) & (6) & (6) & (6) \\
\hline Tag & Improvement & Improvement & Improvement & Improvement & Improvement & Improvement \\
\hline
\end{tabular}




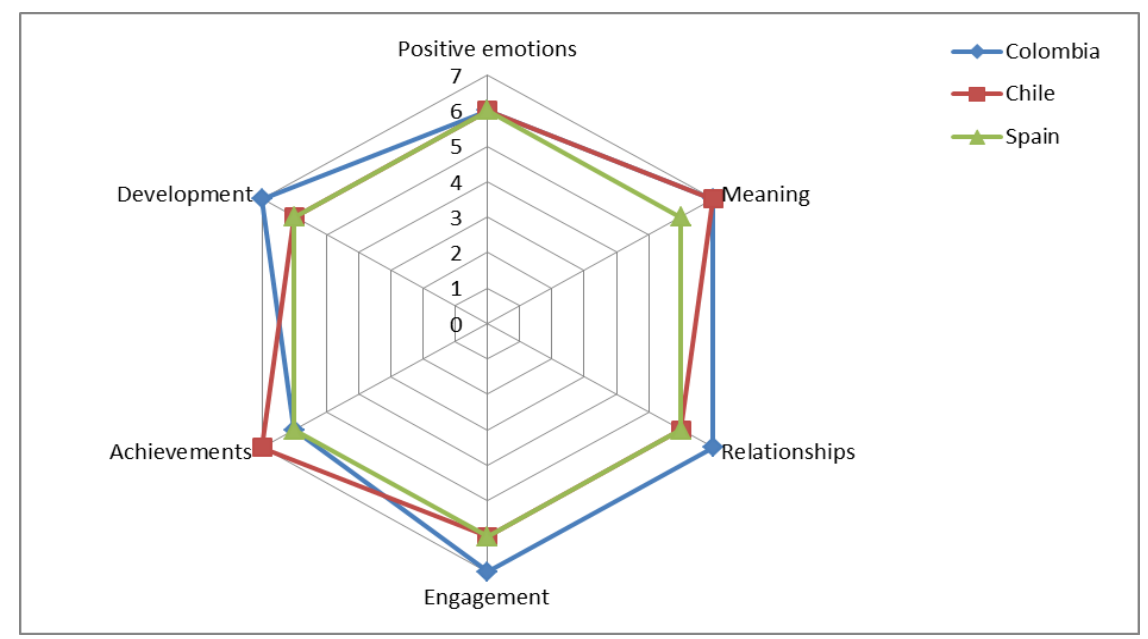

Figure 2. Synthesis values for Chile, Colombia and Spain, 2nd round.

\section{Discussion}

Happiness is understood as part of the quality of life, representing the highest level of well-being. Thus, the combination of sustainability and quality of life or happiness can be considered as the fourth pillar of sustainability [70]. The results of this research paper support the premise that organizational happiness dimensions are important and that their management should be a priority. This confirms the importance of strengthening the dimensions characterizing the concept of organizational happiness to improve performance and productivity, as studied by [9,22-24], without forgetting the implementation of occupational health prevention policies [71], since happiness becomes real when quality of life is sustainable [70].

The results obtained from this research regarding its first goal, to reveal the perceptions of the three groups of experts (academics and support staff) regarding the dimensions of organizational happiness within their respective HEIs, suggest that academics and support staff believe that the dimensions of organizational happiness may experiment improvement and significant improvement within knowledge-intensive work contexts. This is similar to the results regarding happiness at work presented by Salas et al. [21]. Although the differences between countries are not large, Spain's slight lower prospects concur with the less indulgent character of its culture. In addition, Chile's feminine society is reflected in the fact that it was the only country where some respondents attested to not being able to find happiness at work. Colombian respondents, for their part, were the most optimistic ones in both rounds, as befits the most indulgent country. This means that different practices might work differently depending on the environment and the social expectations.

Our results also show how professionals in these institutions are demanding organizational environments which provide stability, continuous opportunities for growth in the company, an excellent work environment where the dimensions of autonomy, recognition, ongoing feedback, meaning and continuous identification with their work exist. However, despite these positive prospects of organizational happiness in the academic industry, there is evidence that the academic environment has changed considerably in the last 20 to 30 years, with a significant increase in stress and occupational health [48], due to the perception of having less autonomy as well as increases in workload, time constraints, highly competitive environments, a perceived lack of positive practices or poor relationships between coworkers [49,50]. Mohammed et al. [72] posit that some HEI staff show undesirable levels of work stress, motivation and satisfaction. Therefore, they recommend organizational offerings such as stress relief programs, wellness fairs and memberships to health clubs; stress management workshops; the use of mobile applications to relieve stress; review of job descriptions to reduce work-related demands; changes in leadership styles that align with the culture 
of the staff; reevaluation of the organizational structure; and better communication between workplace administration and the staff.

To determine future improvement actions related to organizational happiness, it is necessary to identify what is considered relevant by the HEIs' staff, and a way to do so is by asking them directly. The proposed actions, given by the survey's respondents to our third research goal, were generally aligned with the institution's strategic objectives, looking to improve their productivity when teaching, doing research and building a connection with the community and the management itself. Specifically, some of the proposed actions across countries for achieving organizational happiness were; for example, encourage teamwork, improve communication, work-life balance, recognition of achievements, align personal and institutional interests, empathy between peers, free up work time to innovate and maintain common goals and interests.

The most relevant practical implication of this research, a result of the analysis of how these perceptions contribute to SDG No. 3 within an organizational context would be that the development of positive practices in HEIs for managing organizational happiness could yield better performance levels and sustainable workplaces, which in turn would positively contribute to a sustainable and healthy society. It is suggested then, that HEIs leaders and personnel managers identify how to generate activities to contribute to organizational health and well-being. In other words, efforts should be made toward developing an organizational environment that leads to the achievement of satisfaction and happiness at work, promoting adequate job designs, continuous training, career and succession plans, autonomy, meaning, job stability, safety and health, good compensation and benefits, balance of personal and work life, flexibility and recognition, among others, conditions that ensure a true win-win relationship between employees and their company.

In sum, we found that, in terms of organizational happiness, very promising results are expected by the year 2030, since all the dimensions are manifested to improve and/or significantly improve to some degree. This should be thought-provoking because in these times of global social pressures and of questioning the relevance of institutions, it can be seen from the universities studied that there is a general positive outlook regarding the dimensions of organizational happiness for the future. The following question then arises: is a management plan for organizational happiness necessary, considering that the results of this research are so positive and promising? That remains a challenge for future research.

\section{Conclusions, Limitations of the Study and Future Research Lines}

The objective of this research is to analyze the perception of organizational happiness dimensions for HEIs for the next ten years, specifically at the Universidad de Atacama (Chile), Universidad Tecnológica de Bolívar (Colombia) and the Universidad de Alicante (Spain). The results support an imminent and significant improvement in the dimensions related to Positive emotions, Meaning, Reliable relationships, Engagement, Achievement and recognition and Professional and personal development as applied to HEIs.

The results presented in this article have demonstrated the importance of incorporating the concept of happiness management at the organizational level, thus concurring with Fernández [12] and Gutiérrez [13]. The results also encourage reflection on the importance of well-being, quality of life at work and the happiness of staff in the academic development of the institutions, for enabling better performance of their organizational tasks, and pushing toward ethically sustainable environments. In other words, work must be done to promote positive experiences and emotions among staff that allow them to innovate in their work and feel pleasure in what they do.

All three expert panels reflect a similar perceived reality regarding organizational happiness, showing a strong tendency toward expressions of significant improvement. Hence, optimistic future outlooks over the next ten years, regarding the management of organizational happiness dimensions are shown as potential pillars for the implementation of sustainable development practices for people management in HEIs. 
One of the limitations of this study is the limited number of experts available for the Delphi study. Therefore, the results of this study cannot be expanded to the general population, since its methodological design is based on a cross-sectional study of a sample of academics and support staff from HEIs in Spain, Colombia and Chile. It is thus suggested to expand this study to other environments for a contextual analysis of the processes and outcomes of happiness management policies for the development of SDG No. 3. In particular, future researchers could follow the recommendations of Skevington and Epton's work [73] to generate subjective measures for the SDGs to show (a) reliability and validity measurement properties, at a global, regional and national level; (b) an ability to detect positive and negative changes, reflecting experience; (c) acceptability for different cultures and feasibility of use; (d) an evaluation of decision-makers and professionals; (e) the ability to assess healthy people and unhealthy populations; (f) inequalities between groups; and (g) standard procedures to allow cultural adaptation, translation and standardization of new languages. Therefore, this research is open to a wide range of future extensions.

Finally, it would be interesting to conduct a future study on the quantitative investigation of the indicators of organizational happiness dimensions, using confirmatory factor analysis (CFA) tools.

Author Contributions: Conceptualization, J.L.S.M., S.D.J.-E., L.M.-B. and Y.V.A.; Formal analysis, J.L.S.M. and J.O.T.; Funding acquisition, J.L.S.M. and Y.V.A.; Investigation, S.D.J.-E., L.M.-B. and J.O.T.; Methodology, J.L.S.M. and J.O.T.; Project administration, J.L.S.M.; Resources, J.L.S.M., S.D.J.-E., L.M.-B. and Y.V.A.; Validation, S.D.J.-E.; Visualization, S.D.J.-E. and L.M.-B.; Writing—original draft, J.L.S.M., S.D.J.-E., L.M.-B., Y.V.A. and J.O.T.; Writing-review and editing, J.L.S.M., S.D.J.-E. and L.M.-B. All authors have read and agreed to the published version of the manuscript.

Funding: This article is part of the DIUDA Iniciación 2018 Project (Exempt Resolution No. 38 of June 28, 2019), No. 22378 funded by the Universidad de Atacama (Chile). The authors would like to express their thanks to everyone who contributed to the research.

Conflicts of Interest: J.L.S.M., Y.V.A. and J.O.T. have received a grant from the Universidad de Atacama (Chile), part of the DIUDA Iniciación 2018 with No. 22378. The authors declare that the sponsors had no role in the design, execution, interpretation, or writing of the study. S.D.J.-E. is an elected union member in her university. This did not affect the design, execution, interpretation, or writing of the study.

\section{References}

1. United Nations. Transforming Our World: The 2030 Agenda for Sustainable Development. 2015. Available online: https://sustainabledevelopment.un.org/content/documents/21252030\%20Agenda\%20for\% 20Sustainable\%20Development\%20web.pdf (accessed on 12 September 2020).

2. Monteiro, N.B.R. Sustainable development goals in mining. J. Clean. Prod. 2019, 228, 509-520. [CrossRef]

3. United Nations. The Sustainable Development Agenda. Available online: https://www.un.org/ sustainabledevelopment/development-agenda/ (accessed on 12 September 2020).

4. Li, Y.; Zhu, X. The 2030 Agenda for Sustainable Development and China's Belt and Road Initiative in Latin America and the Caribbean. Sustainability 2019, 11, 2297. [CrossRef]

5. Sweileh, W.M. Bibliometric analysis of scientific publications on "sustainable development goals" with emphasis on "good health and well-being" goal (2015-2019). Glob. Health 2020, 16, 68. [CrossRef] [PubMed]

6. Warr, P. Fuentes de felicidad e infelicidad en el trabajo: Una perspectiva combinada. Rev. De Psicol. Del Trab. Y De Las Organ. 2013, 29, 99-106. [CrossRef]

7. de Sousa, J.M.; Porto, J.B. Happiness at Work: Organizational Values and Person-Organization Fit Impact. Paid. (Ribeirão Preto) 2015, 25, 211-220. [CrossRef]

8. Joo, B.-K.; Lee, I. Workplace happiness: Work engagement, career satisfaction, and subjective well-being. Evid. Based HRM 2017, 5, 206-221. [CrossRef]

9. Hosie Peter, J.; Sevastos, P. Does the "happy-productive worker" thesis apply to managers? Int. J. Workplace Health Manag. 2009, 2, 131-160. [CrossRef]

10. Semedo Ana, S.; Coelho, A.; Ribeiro, N. Authentic leadership, happiness at work and affective commitment: An empirical study in Cape Verde. Eur. Bus. Rev. 2019, 31, 337-351. [CrossRef]

11. Seligman, M. Florecer-Bienestar y Felicidad; Ed. Zeta Bolsillo: Barcelona, Spain, 2011. (In Spanish) 
12. Fernández, I. Felicidad Organizacional: Como Construir Felicidad En El Trabajo; B Grupo Z: Santiago de Chile, Chile, 2015. (In Spanish)

13. Gutiérrez, V. Principios de la Felicidad Organizacional; Ediciones Granica: Ciudad de México, Mexico, 2015. (In Spanish)

14. Singh, S.; David, R.; Mikkilineni, S. Organizational Virtuousness and Work Engagement: Mediating Role of Happiness in India. Adv. Dev. Hum. Resour. 2017, 20, 88-102. [CrossRef]

15. Dima, A.M.; Meghisan-Toma, G.-M. Reserch on implementing education for sustainable development. Proc. Int. Conf. Bus. Excel. 2018, 12, 300-310. [CrossRef]

16. Leal Filho, W.; Skanavis, C.; Kounani, A.; Brandli, L.L.; Shiel, C.; Paço, A.D.; Pace, P.; Mifsud, M.; Beynaghi, A.; Price, E.; et al. The role of planning in implementing sustainable development in a higher education context. J. Clean. Prod. 2019, 235, 678-687. [CrossRef]

17. Pfeffer, J. Building sustainable organizations: The human factor. Acad. Manag. Perspect. 2010, $24,34-45$.

18. Saqib Zulkaif, A.; Zhang, Q.; Ou, J.; Saqib Khubaib, A.; Majeed, S.; Razzaq, A. Education for sustainable development in Pakistani higher education institutions: An exploratory study of students' and teachers' perceptions. Int. J. Sustain. High. Educ. 2020, 21, 1249-1267. [CrossRef]

19. Boehm, J.K.; Lyubomirsky, S. Does Happiness Promote Career Success? J. Career Assess. 2008, 16, 101-116. [CrossRef]

20. Tseng, M.-L. Application of ANP and DEMATEL to evaluate the decision-making of municipal solid waste management in Metro Manila. Environ. Monit. Assess. 2009, 156, 181-197. [CrossRef]

21. Salas-Vallina, A.; Alegre, J.; Fernández Guerrero, R. Happiness at work in knowledge-intensive contexts: Opening the research agenda. Eur. Res. Manag. Bus. Econ. 2018, 24, 149-159. [CrossRef]

22. Ravina Ripoll, R.; Villena Manzanares, F.; Gutiérrez Montoya, G.A. Una aproximación teórica para mejorar los resultados de innovación en las empresas desde la perspectiva del Happiness Management. Retos. Rev. De Cienc. De La Adm. Y Econ. 2017, 7, 113-129. (In Spanish) [CrossRef]

23. Dolan, P.; Metcalfe, R. The relationship between innovation and subjective wellbeing. Res. Policy 2012, 41, 1489-1498. [CrossRef]

24. Rego, A.; Ribeiro, N.; Cunha, M.P.E.; Jesuino, J.C. How happiness mediates the organizational virtuousness and affective commitment relationship. J. Bus. Res. 2011, 64, 524-532. [CrossRef]

25. Gavin, J.H.; Mason, R.O. The Virtuous Organization: The Value of Happiness in the Workplace. Organ. Dyn. 2004, 33, 379-392. [CrossRef]

26. Seligman, M. Florecer. La Nueva Psicología Positiva Y La Búsqueda Del Bienestar; Editorial Océano Exprés: Ciudad de Mexico, Mexico, 2016.

27. Carr, A.; Cullen, K.; Keeney, C.; Canning, C.; Mooney, O.; Chinseallaigh, E.; O'Dowd, A. Effectiveness of positive psychology interventions: A systematic review and meta-analysis. J. Posit. Psychol. 2020, 1-21. [CrossRef]

28. Park, N.; Peterson, C.; Sun, J.K. La Psicología Positiva: Investigación y aplicaciones. Ter. Psicológica 2013, 31, 11-19. [CrossRef]

29. World Health Organization. Promoting Mental Health: Concepts, Emerging Evidence, Practice (Summary Report); World Health Organization: Geneva, Switzerland, 2004.

30. Moskowitz, J.T.; Cheung, E.O.; Freedman, M.; Fernando, C.; Zhang, M.W.; Huffman, J.C.; Addington, E.L. Measuring Positive Emotion Outcomes in Positive Psychology Interventions: A Literature Review. Emot. Rev. 2020, 1754073920950811. [CrossRef]

31. Oades, L.G.; Ozturk, C.; Hou, H.; Slemp, G.R. Wellbeing literacy: A language-use capability relevant to wellbeing outcomes of positive psychology intervention. J. Posit. Psychol. 2020, 15, 696-700. [CrossRef]

32. Yamaguchi, K.; Takebayashi, Y.; Miyamae, M.; Komazawa, A.; Yokoyama, C.; Ito, M. Role of focusing on the positive side during COVID-19 outbreak: Mental health perspective from positive psychology. Psychol. Trauma Theory Res. Pract. Policy 2020, 12, S49-S50. [CrossRef]

33. Appiah, R.; Wilson-Fadiji, A.; Schutte, L.; Wissing, M.P. Effects of a Community-Based Multicomponent Positive Psychology Intervention on Mental Health of Rural Adults in Ghana. Appl. Psychol. Health Well-Being 2020, 12, 828-862. [CrossRef]

34. Watanabe, K.; Kawakami, N.A.-O.; Shiotani, T.; Adachi, H.; Matsumoto, K.; Imamura, K.; Yamagami, F.; Fusejima, A.; Muraoka, T.; Kagami, T.; et al. The Japanese Workplace PERMA-Profiler: A validation study among Japanese workers. J. Occup. Health 2018, 60, 383-393. [CrossRef] 
35. Fisher, C.D. Happiness at Work. Int. J. Manag. Rev. 2010, 12, 384-412. [CrossRef]

36. Huang, K.; Pearce, P.L.; Wu, M.-Y.; Wang, X.-Z. Tourists and Buddhist heritage sites: An integrative analysis of visitors' experience and happiness through positive psychology constructs. Tour. Stud. 2019, 19, 549-568. [CrossRef]

37. Wagner, L.; Gander, F.; Proyer, R.T.; Ruch, W. Character Strengths and PERMA: Investigating the Relationships of Character Strengths with a Multidimensional Framework of Well-Being. Appl. Res. Qual. Life 2020, 15, 307-328. [CrossRef]

38. Tansey, T.N.; Smedema, S.; Umucu, E.; Iwanaga, K.; Wu, J.-R.; Cardoso, E.D.S.; Strauser, D. Assessing College Life Adjustment of Students With Disabilities: Application of the PERMA Framework. Rehabil. Couns. Bull. 2017, 61, 131-142. [CrossRef]

39. Volet, S.; Seghezzi, C.; Ritchie, S. Positive emotions in student-led collaborative science activities: Relating types and sources of emotions to engagement in learning. Stud. High. Educ. 2019, 44, 1734-1746. [CrossRef]

40. Edwards, J.R.; Cable, D.M. The value of value congruence. J. Appl. Psychol. 2009, 94, 654-677. [CrossRef] [PubMed]

41. Kahn, W.A. Psychological Conditions of Personal Engagement and Disengagement at Work. Acad. Manag. J. 1990, 33, 692-724.

42. Bakker, A.B.; Demerouti, E. Towards a model of work engagement. Career Dev. Int. 2008, 13, $209-223$. [CrossRef]

43. Silvestro, R.; Cross, S. Applying the service profit chain in a retail environment: Challenging the "satisfaction mirror". Int. J. Serv. Ind. Manag. 2000, 11, 244-268. [CrossRef]

44. Collén, K. Education for a sustainable future? Students' experiences of workshops on ethical dilemmas. Soc. Work Educ. 2019, 38, 119-128. [CrossRef]

45. Cebrián, G.; Junyent, M. Competencies in Education for Sustainable Development: Exploring the Student Teachers' Views. Sustainability 2015, 7, 2768. [CrossRef]

46. Chisingui, A.V.; Costa, N. Teacher Education and Sustainable Development Goals: A Case Study with Future Biology Teachers in an Angolan Higher Education Institution. Sustainability 2020, 12, 3344. [CrossRef]

47. Kuwaiti Ahmed, A.; Bicak Hasan, A.; Wahass, S. Factors predicting job satisfaction among faculty members of a Saudi higher education institution. J. Appl. Res. High. Educ. 2019, 12, 296-310. [CrossRef]

48. Mark, G.; Smith, A.P. Effects of occupational stress, job characteristics, coping, and attributional style on the mental health and job satisfaction of university employees. Anxiety Stress Coping 2012, 21, 63-78. [CrossRef] [PubMed]

49. Chan, H.; Mazzucchelli, T.G.; Rees, C.S. The battle-hardened academic: An exploration of the resilience of university academics in the face of ongoing criticism and rejection of their research. High. Educ. Res. Dev. 2020, 1-15. [CrossRef]

50. Janse van Rensburg, C.; Rothmann, S. Towards positive institutions: Positive practices and employees' experiences in higher education institutions. SA J. Ind. Psychol. 2020, 46, 1733. [CrossRef]

51. Del Canto Viterale, F. University as a global actor in the international system of the 21st Century. Tuning J. High. Educ. 2018, 6, 169-198. [CrossRef]

52. Frølich, N.; Christensen, T.; Stensaker, B. Strengthening the strategic capacity of public universities: The role of internal governance models. Public Policy Adm. 2018, 34, 475-493. [CrossRef]

53. Lin, H.-Y. Perceptions of the Englishization of higher education in Taiwan: Implementation and implications. Int. J. Biling. Educ. Biling. 2020, 23, 617-634. [CrossRef]

54. Hofstede, G. Culture's Consequences: Comparing Values, Behaviors, Institutions, and Organizations across Nations, 2nd ed.; Sage Publications: Thousand Oaks, CA, USA, 2001.

55. Hofstede, G.; Hofstede, G.J.; Minkov, M. Cultures and Organizations: Software of the Mind, 3rd ed.; McGraw-Hill: New York, NY, USA, 2010.

56. Arapé, J. Manual de metodologías. Tomo III: La Técnica Delphi; Programa de Prospectiva Tecnológica de la Secretaría de las Naciones Unidas para el Desarrollo Industrial (ONUDI): Vienna, Austria, 2000.

57. Ajzen, I. The theory of planned behaviour is alive and well, and not ready to retire: A commentary on Sniehotta, Presseau, and Araújo-Soares. Health Psychol. Rev. 2015, 9, 131-137. [CrossRef]

58. Dalkey, N.; Helmer, O. An Experimental Application of the DELPHI Method to the Use of Experts. Manag. Sci. 1963, 9, 458-467. [CrossRef]

59. Linstone, H.; Turoff, M. The Delphi Method; Addison-Wesley: Reading, MA, USA, 1975. 
60. Murphy, F.; Doody, O.; Lyons, R.; Gallen, A.; Nolan, M.; Killeen, A.; Kavanagh, P.; Donegan, J.; Sezgin, D. The development of Nursing Quality Care Process Metrics and Indicators for use in Older Persons Care Settings: A Delphi-Consensus Study. J. Adv. Nurs. 2019, 75, 3471-3484. [CrossRef]

61. Allen, M.S.; McCarthy, P.J. Be Happy in your Work: The Role of Positive Psychology in Working with Change and Performance. J. Chang. Manag. 2016, 16, 55-74. [CrossRef]

62. Bassi, M.; Bacher, G.; Negri, L.; Delle Fave, A. The Contribution of Job Happiness and Job Meaning to the Well-Being of Workers from Thriving and Failing Companies. Appl. Res. Qual. Life 2013, 8, 427-448. [CrossRef]

63. Carlquist, E.; Ulleberg, P.; Delle Fave, A.; Nafstad, H.E.; Blakar, R.M. Everyday Understandings of Happiness, Good Life, and Satisfaction: Three Different Facets of Well-being. Appl. Res. Qual. Life 2017, 12, 481-505. [CrossRef]

64. Lavy, S.; Bocker, S. A path to teacher happiness? A sense of meaning affects teacher-student relationships, which affect job satisfaction. J. Happiness Stud. Interdiscip. Forum Subj. Well-Being 2018, 19, 1485-1503. [CrossRef]

65. Pryce-Jones, J.; Lindsay, J. What happiness at work is and how to use it. Ind. Commer. Train. 2014, 46, 130-134. [CrossRef]

66. De Waal, A. Increasing organisational attractiveness. J. Organ. Eff. People Perform. 2018, 5, 124-141. [CrossRef]

67. Rowe, G.; Wright, G. Expert Opinions in Forecasting: The Role of the Delphi Technique. In Principles of Forecasting. International Series in Operations Research \& Management Science; Armstrong, J.S., Ed.; Springer: Boston, MA, USA, 2001; Volume 30.

68. López-de-Arana Prado, E.; Aramburuzabala Higuera, P.; Opazo Carvajal, H. Diseño y validación de un cuestionario para la autoevaluación de experiencias de aprendizaje-servicio universitario. Educ. Xx1 2019, 23, 319-347. (In Spanish)

69. Van Zolingen, S.J.; Klaassen, C.A. Selection processes in a Delphi study about key qualifications in Senior Secondary Vocational Education. Technol. Forecast. Soc. Chang. 2003, 70, 317-340. [CrossRef]

70. František, P.; František, M. Linking sustainability and happiness. What kind of happiness? GeoScape 2020, 14, 70-79.

71. Braks, M.; Giglio, G.; Tomassone, L.; Sprong, H.; Leslie, T. Making Vector-Borne Disease Surveillance Work: New Opportunities from the SDG Perspectives. Front. Vet. Sci. 2019, 6, 232. [CrossRef]

72. Mohammed, D.; Chan, E.; Ahmad, R.; Dusic, A.; Boglarsky, C.; Blessinger, P.; Zeine, R. Health implications of job-related stress, motivation and satisfaction in higher education faculty and administrators. J. Appl. Res. High. Educ. 2019, 12, 725-741. [CrossRef]

73. Skevington, S.M.; Epton, T. How will the sustainable development goals deliver changes in well-being? A systematic review and meta-analysis to investigate whether WHOQOL-BREF scores respond to change. BMJ Glob. Health 2018, 3, e000609. [CrossRef] [PubMed]

Publisher's Note: MDPI stays neutral with regard to jurisdictional claims in published maps and institutional affiliations.

(C) 2020 by the authors. Licensee MDPI, Basel, Switzerland. This article is an open access article distributed under the terms and conditions of the Creative Commons Attribution (CC BY) license (http://creativecommons.org/licenses/by/4.0/). 